\title{
Microbial Fingerprinting of Potential Biodegrading Organisms
}

\author{
Bishwambhar Mishra $^{1}$ - Sunita Varjani ${ }^{2}$ - Gayathri Priya Iragavarapu ${ }^{3} \cdot \mathrm{Huu}_{\mathrm{Hao}} \mathrm{Ngo}^{4} \cdot$ Wenshan Guo $^{4}$. \\ Bhushan Vishal ${ }^{5}$
}

\begin{abstract}
The world is witnessing various pollutants in the environment since the last few decades that threaten human life. The biological responses to various pollutants show variations as the living system behaves differently in their sensitivities to the same types of pollutants. The relative response and activity depend upon the duration of exposure to the specific pollutant. It is impossible to stop various activities leading to environmental pollution; however, pollutants can be eliminated from the environment using the microorganisms. Application of biological processes can be executed in order to get rid of toxic pollutants through their biodegradation. The pollutants like hydrocarbons, heavy metals, chlorinated hydrocarbons, nitroaromatic compounds, non-chlorinated herbicides and pesticides, organophosphates, radionuclides can lead to serious health and environmental problems. The main objective of this paper is to evaluate the effects of pollutants on the living beings and environment, microbial responses to pollution, and distribution of various biodegrading microorganisms in the environment. Profiling of biodegrading microor-ganisms, microbial biosensor to detect environmental pollution, and strain improvement through genetic manipulation to enhance the biodegradation process have been discussed in detail.
\end{abstract}

Keywords Biodegradation $\cdot$ Pollutant $\cdot$ Microbial diversity $\cdot$ Genetic manipulation $\cdot$ Biosensor

\section{Introduction}

The ever-growing industrialization and population are the main cause for disturbing the sustainability of our planet $[56,69]$. Various types of mining industries, power plants, and petroleum refineries are the primary sources of hazardous

\section{Sunita Varjani}

drsvs18@gmail.com

Department of Biotechnology, Centurion University of Technology and Management, Bhubaneswar, Odisha 752 050, India

Gujarat Pollution Control Board, Gandhinagar, Gujarat 382010, India

Department of Biotechnology, Sreenidhi Institute of Science and Technology, Hyderabad, Telangana 501 301, India

Centre for Technology in Water and Wastewater, School of Civil and Environmental Engineering, University of Technology Sydney, Sydney, NSW 2007, Australia

Department of Biological Sciences, National University of Singapore, Singapore 117 543, Singapore and toxic materials that lead to pollution of air, water, and land ecosystem $[51,69,156,187]$. The enormous release of wastewaters, slurries, solid wastes, and industrial effluents are affecting water and soil quality. As the natural ecosystem is deteriorating, the intrinsic remediation power of the earth is also getting reduced [163]. Most of the pollutants can be degraded and metabolized by natural activities of microorganisms. Microorganisms can initiate several types of reactions through metabolism that include oxidation-reduction, substitution, hydrolysis, cleavage, dehydrohalogenation, dechlorination, and dehydrogenation $[106,139,153]$. Although pollutants and toxicants affect microorganisms, they can enhance the rates of their degradation. The scientific knowledge upon microbial interactions with pollutants has helped to address the environmental pollution in the last decades [161].

Land disturbance, pollution, overpopulation, landfill, and deforestation are the major causes of ecosystem destruction. The researchers are now exploring restoration of ecosystem by using the communities such as biocrusts (communities of mosses, lichens, cyanobacteria, and other microorganisms) living on the soil surface of the drylands. Biocrusts strongly affect key processes in the ecosystem such as soil erosion, nitrogen and carbon cycling, and nutritional status [173]. Successful restoration of the 
drylands from China, Israel, and the USA has been established by using this biocrust [173].

Microbial pathways associated with degradation of different groups of hazardous chemicals and pollutants have been thoroughly investigated for decades [56]. Scientists have developed a unique methodology to remediate organic pollutants in aerobic or anaerobic condition. Some important enzymes (peroxidases, oxygenases, hydroxylases, reductases, and dehydrogenases) commonly catalyze the biodegradation of major pollutants in both aerobic and anaerobic conditions [98].

In the aerobic conditions, oxygen is the final electron acceptor. In some of the catabolic process, oxygen can also act as a co-substrate $[34,38,46,49,186]$. The biodegradation of hydrocarbons like petroleum pollutants in the aerobic process is mediated with the intracellular attack of organic hydrocarbons initially. This is an oxidation process, in which activation and incorporation of molecular oxygen is the key reaction catalyzed by the enzymes like peroxidases and oxygenases $[1,155]$. Aromatic groups like benzene are cleaved or degraded by the microorganism through the activity of two enzymatic systems viz. dioxygenases and monooxygenases [90, 163]. Anaerobic degradation of the pollutants has been reported under reducing conditions. In this methodology, four enzymatic reactions are involved (a) addition of fumarate (catalyzed by a glycyl radical enzyme), (b) methylation of unsubstituted aromatics, (c) alkyl substituent hydroxylation (catalyzed by a dehydrogenase), and (d) direct carboxylation [163].

Biodegradation is a sustainable and eco-friendly process, which can remove the organic pollutants from the environment more efficiently with the help of microorganisms [103, $162,163]$. The main objective of biodegradation is to remove pollutants present from the ecosystem without creating problems in the biological processes associated with it. As compared to other methodologies, the biodegradation is considered universally as it provides the best results with costeffective inputs [157].

\section{Types of Pollutants in the Environment}

The pollutants are diversified in different places. Some of them are persistent by nature in the environmental degradation (biological, chemical, and photolytic reactions) process and stay for a long time. Several alicyclic, aliphatic, and aromatic compounds are the major groups of pollutants produced from pharmaceutical and chemical industries. They reach the soil or aquatic environment through different routes [23, 56, 104, 161].

\section{Organic Pollutants}

Organic pollutants are unstable thermodynamically. They can be converted to harmless and non-toxic products through the physicochemical action (volatilization, photodecomposition, leaching, and partitioning) and biological action like microbial metabolism and phytoremediation. Sometimes, the concentration of these organic pollutants can be elevated to a higher extent if they are applied over short periods at high concentrations repeatedly [46, 157]. Various recalcitrant organic compounds create serious environmental hazards that are found to be persistent in soil and water environments [56, 156]. The major pollutants like polycyclic aromatic hydrocarbons (PAHs), organochlorine pesticides (OCPs), polychlorinated biphenyls (PCB), dioxins, and dibenzofurans are the major groups of persistent organic pollutant $[73,165]$. The degradation patterns of these organic pollutants are also different with respect to chemical nature. Degradation of OCPs is mediated through the non-oxidative pathway/ hydrolytic pathway and for polychlorinated biphenyls, generally, anaerobic degradation takes place starting with dehalogenase enzyme. Similarly, the degradation of dibenzofurans is mediated through two main pathways (angular and lateral deoxygenation) and dioxins through reductive dehalogenation.

These kinds of compounds are non-biodegradable in nature. Hence, they remain intact in the ecosystem for a long duration of time. They are also resistant to chemical, photolytic, and biological degradation. They can easily get accumulated in the adipose tissue of the human body through the food chain. Hence, they cause harmful effects to the living system as well as the environment $[23,166]$. Various groups of organic pollutants have been highlighted in Fig. 1.

\section{Inorganic Pollutants}

Inorganic pollutants are found to be non-biodegradable by nature. They can be transformed from one state to another. Various groups of heavy metals and metalloids are examples of inorganic pollutants. These can be deposited in the soil and may leach to groundwater. Various groups of inorganic pollutants have been highlighted in Fig. 2.

Any metallic element having high density than water and toxic in nature at very low concentrations are known as "heavy metal" [78]. Various groups of heavy metals like mercury $(\mathrm{Hg})$, chromium $(\mathrm{Cr})$, cadmium $(\mathrm{Cd})$, arsenic (As), and lead $(\mathrm{Pb})$ are found to be non-biodegradable, toxic, and persistence by nature [52].

\section{Mixture of Inorganic and Organic Pollutants}

The pollutants from organic and inorganic sources and their combinations can be obtained as anthropogenic or in a natural way. For example, mollusk shells, crustacean carapaces, and teeth and bone tissues in vertebrates are present as organicinorganic composites in nature. Some of them are found to be organometallic derivatives. They also include rodent repellants, fungicides, molluscicides, ovicides, miticides, nematocides, 
Fig. 1 Categories of organic pollutants

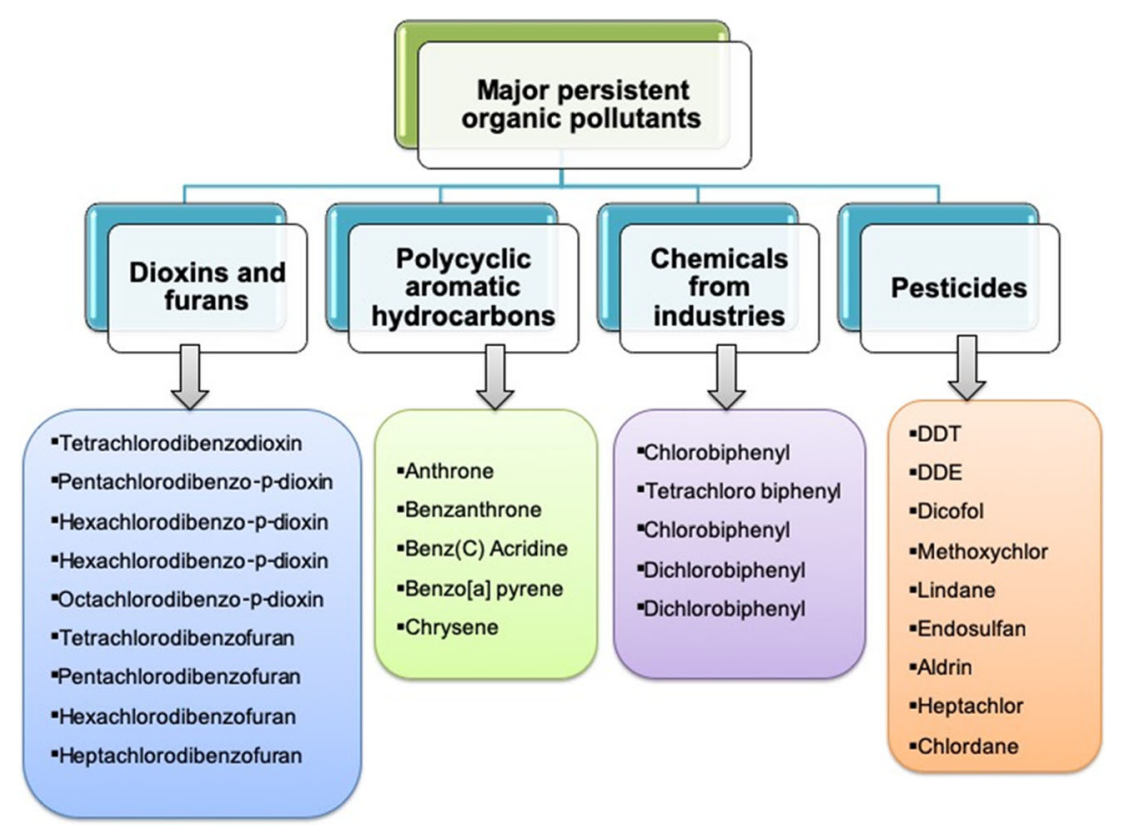

antifouling paints, and wood preservatives. The waste materials from the industries (petroleum refining or mixed effluents) that release such agents reaching out the soil ecosystem. Most of the coloring agents used commercially are composed of inorganic pigments suspended in organic mixtures. Those are widely used as organic-inorganic industrial agents. Many hybrid organic-inorganic nano-composites have also developed for its use in the new catalysts, sensors, and smart membranes. These hybrid organic-inorganic nano-composites are being used to remediate volatile organic compounds (VOCs), such as ethanol and isopropyl alcohol into harmless products. The authors have executed the photocatalysis in order to recover pure water from the pollutant sample. The degradation kinetics for isopropyl alcohol was noted $0.0859 \mathrm{~min}^{-1}$ when PVDF/P25/CuxOy inorganic-organic hybrid membranes were used [72]. The hybrid of polypyrrole/titanium (IV) was successfully synthesized and was applied for remediation of $\mathrm{Cr}$ (VI) from wastewater [66]. Javadian [67] fabricated a hybrid polymer of polyaniline/polypyrrole to remove the heavy metals like Co (II) from the water sample. It has been reported that Pseudomonas aeruginosa, Sphingomonas sp., Pseudomonas putida, Aspergillus niger, Bacillus cereus, Arthrobacter sp., etc. can degrade the compounds composed of both organics and inorganics [178].
Fig. 2 Categories of inorganic pollutants

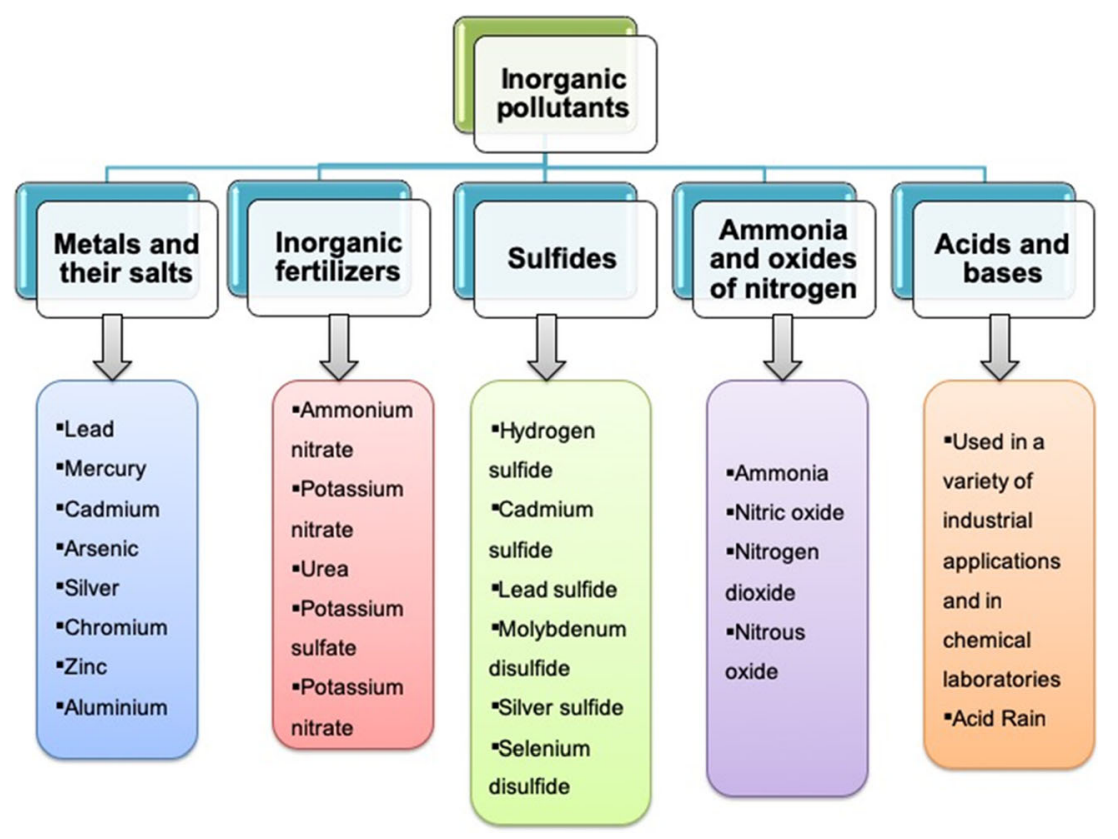




\section{Microbial Responses to Pollution}

The behavior of microorganisms and their response to pollutants has been investigated elaborately. The pollution that occurred by the human made the microorganisms to response initially. Modifications in the structure of a microbial community and their changes in genetic composition have been largely noticed subjected to the addition of organic pollutant $[144,163]$ and inorganic pollutant [118]. In accordance with these investigations, different communities of microorganisms have been described in polluted environments in accordance with the characteristics of the pollutant $[42,101,154]$. The above observations in the microbial community level are relevant to provide information with respect to the exposure of pollutants on the behavior of microbial communities.

Recently, different studies have been executed to assess the microbial activities and metabolic capacity during the course of biodegradation of the pollutants [13, 39]. The metabolism of pollutants in the microbial community is related to genetic adaptation techniques which include horizontal gene transfer and mutations [115, 159]. Various genotoxicity methodologies have been assayed using microorganisms for the evaluation of their toxicity in the polluted sites [93]. The genotoxicity assays have been also executed with different plant species for various groups of pollutants released with industrial effluents to monitor the toxicity. The plant like Allium cepa, Vicia faba, and Vigna radiate was used to study the effluents of pulp and paper mill, Tannery effluent, textile industry wastewater, and industrial dye effluents [77, 128, 181]. Generally, root tip cells were observed with the chromosomal aberrations (delayed anaphase, C-mitosis, stickiness, chromosome break, chromosome bridge) upon exposure with the pollutants. The physiological and metabolic characteristics have been studied for better understanding the microbial behavior and their capacities to react with pollutants. The various approaches with respect to pollutants that show responses starting from the molecular level to ecosystem level, their process of adaptation, detection tools, and culture-independent approaches have been outlined in Fig. 3.

Resistance to the various groups of pollutants may be due to overexpression of the genes responsible for tolerating the pollutants. This can be effective through mutation and horizontal gene transfer that lead to acquiring new pollutanttolerant microorganisms. The history of pollution at a particular site also determine promptly mobilized in subsequent exposure. The rate of biodegradation of the particular pollutants also found to be faster as compared to previously exposed [11]. Hence, memory effect also increases the tolerance for the microbial community to the pollutants $[81,97]$.

\section{Biodegrading Microorganisms}

\section{Distribution of Organic Pollutants Degrading Microorganisms}

In general, every microorganism can remediate the pollutants, but few engineered microorganisms are also capable of remediating pollutants effectively. Some of the microorganisms like Staphylococcus, Streptococcus, Bacillus, Escherichia, Klebsiella, Corynebacterium, Shigella, Alcaligenes, Pseudomonas, Acinetobacter, and Enterobacter have been extensively applied for the biodegradation of persistent organic pollutants (POPs) [78, 95, 158, 160]. Among these microorganisms, Bacillus sp. has been extensively employed in the removal of organic pollutants [82]. The microorganisms upon action either change the functional groups present in the pollutant or change the structure of the compound into a lesser toxic form. This leads to the formation of inorganic salts, water, and $\mathrm{CO}_{2}$. Among the microbial community, bacteria, fungi, and algae have the ability to transform the POPs into simpler non-toxic metabolites [2, 73, 116, 154].

Successful biodegradation of hydrocarbons, dioxins, furans, PAH, PCB, and DDT by the action of microorganisms has been reported previously. Some of bacterial strains like Alcaligenes sp. SSK1B, Microbacterium sp. BPW, and Achromobacter sp. SSK4 are able to remediate PAHs [167, 174]. In some studies, a bacterial consortium of Bacillus sp., Pseudomonas aeruginosa, Pseudomonas putida, Acinetobacter sp., Acinetobacter sp., Proteus sp. Citrobacter freundii, Stenotrophomonas sp., Flavobacterium sp., and Proteus vulgaris could able to degrade pesticides successfully [68, 109, 156, 165]. The Streptomyces strains could degrade chlordane and $56 \%$ through reduction of $\Upsilon$-chlordane. Degradation of organochlorine pesticides by Alcaligenes faecalis JBW4 was studied by some researchers and it was concluded that the isolate of JBW4 strain possessed efficient capacity to degrade the endosulfan residue $[31,76]$.

Fungi are known to be the potential biodegrading agent. They can destroy and deteriorate various kinds of materials like leather, plastic, textile, wood, and paper. It was reported that PAH can be metabolized by microorganisms. Some researchers had investigated the white-rot fungal cultures are potential to degrade PAH [20,147]. Various groups of enzymes (manganese peroxidase, laccases, and lignin peroxidises) are biosynthesized by different groups of fungus, which can enhance the degradation rate of dyes, pesticides, polychlorinated biphenyls, chlorinated and phenolic compounds, hydrocarbons, etc. [103, 147]. Some fungal species like Fusarium oxysporum, Mucor alternans, Phanerochaete chrysosporium, and Tricoderma viride can degrade DDT efficiently. The degradation of benzo- $(\alpha)$ pyrene by Pleurotus ostreatus for the synthesis of ligninolytic enzyme was also investigated. Oxidation of various pollutants like pyrene, 
Fig. 3 Microbial responses to the pollution at different biological organization levels

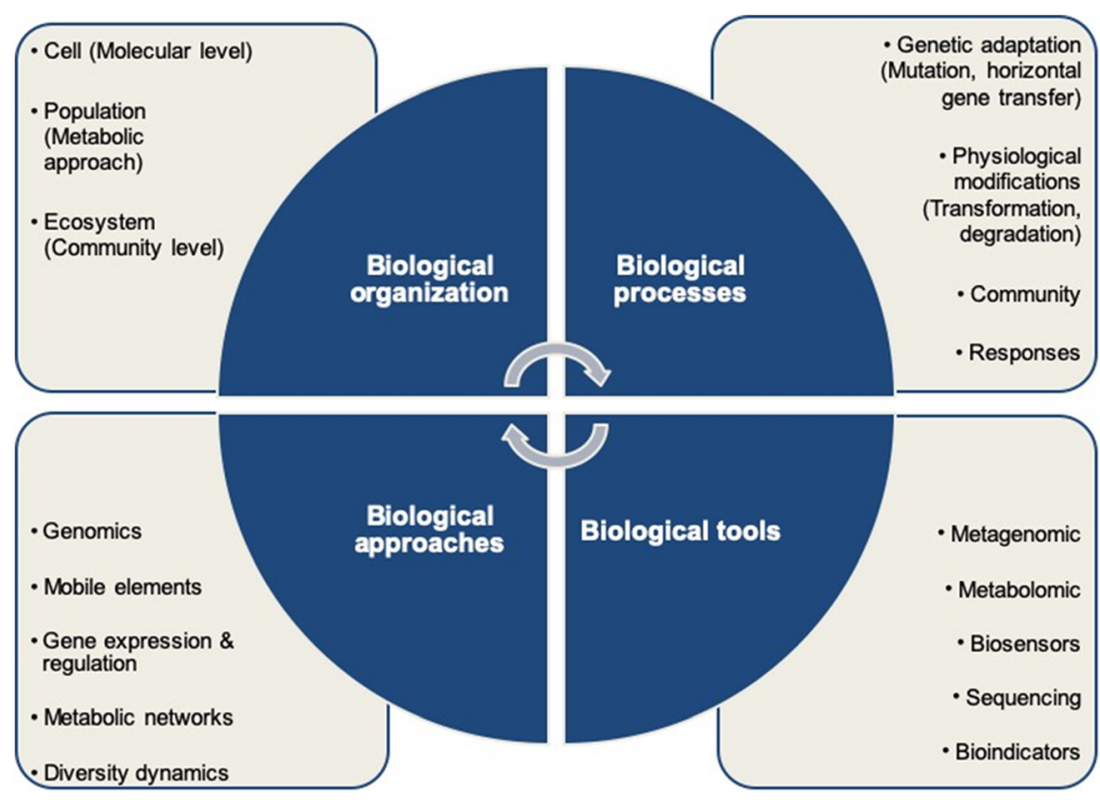

microorganism through sulfate transporters. After that, it reduces to $\mathrm{Cr}$ (III) through the formation of unstable intermediates, i.e., $\mathrm{Cr}(\mathrm{V} / \mathrm{IV})$ [125].

\section{Profiling of Biodegrading Microorganisms}

The culture-dependent method generally recovers a small portion of the diversity from environments [151]. However, culture-independent approaches (transcriptomic, metabolomic, proteogenomic, and metagenomic studies) lead to specific degradation pathways [153]. Pollution history at a specific site also matters a lot. This is due to exposure of the microbial community to the pollutant previously able to act promptly in the subsequent exposure [81]. This increased level of tolerance of the microorganisms to the pollutants is due to community shifts or physiological adaptations [11, 97]. Recently, some researchers have reported regarding the shifting of microbial community structure and changes in abundance of some species with respect to high concentrations of pollutants in the ecosystem [70,101]. The microbial resistance and adaptation to specific pollutants may operate through overexpression or higher frequency of genes of new genetic tolerance-related capabilities horizontal gene transfer and mutation [171].

The culture-based methodology is applicable in studying microbial ecosystem of contaminated and natural environments; however, they are not providing solutions to analyze microbial genetic diversity [164]. It was found $>99 \%$ of prokaryotes present totally in any given environmental sample can be calculated through molecular analysis in nonculturable fraction [65]. Our biosphere is diversified with microorganisms which constitute $60 \%$ of the Earth's biomass hexavalent chromium $\mathrm{Cr}$ (VI) gets into the cell of the 
approximately [140]. The microbial catabolic diversity along with functional aspect is very important to understand biodegradation process of environmental pollutants. Traditional techniques for culturing the microorganisms deal with commercially available growth mediums (nutrient agar medium, LB Agar medium, etc.) for characterization of microorganisms obtained from the environmental sample [120]. The culturedependent methodologies are useful to characterize the very small population and diversity $(<1 \%)$ of microorganisms in any polluted sites. The microorganisms which are viable in the natural environment and they are not cultivable in the laboratory conditions are known as viable but non-culturable (VBNC) organisms [108]. In general, VBNC organisms possess novel group and are found to be more active in the bioremediation process [120]. In culture-independent methods, the primary source of information can easily be obtained that lies in nucleic acids, lipids and proteins.

Broadly, the functional and compositional diversity of microorganisms are analyzed by various techniques viz. clone libraries, DNA microarray, isotope array, genetic fingerprinting, in situ hybridization, etc. The post-genomic approaches like metaproteomics, metatranscriptomics, and proteogenomics help researchers to assess the composition of microbial diversity in the contaminated site [164]. However, the post-genomic approaches have their own limitations. Sometimes, very low level or un-expressible environmental genes present in the microorganisms. It can be improved by transforming metagenomic DNA into several additional surrogate hosts such as Pseudomonas, Bacillus, Streptomyces, and Agrobacterium. In many cases, isolation of genomic DNA from pollutant sites (sludge, wastewater, sediment or soil) is challenging as per its quality, molecular size, and representation of all microbial genomes. Sometimes, inhibitory contaminants are frequently found, and DNA is found to be shared with low-size fragments. Heavily pollutant-affected sites often harbor very low cell densities. Therefore, metagenomic DNA cannot be extracted directly and unable to produce enough genomic material for the construction of the library. Profiling pattern with respect to various methodologies has been illustrated in Fig. 4.

\section{Clone Library}

In the clone library method, PCR-based method is usually followed. In this method, the total DNA/RNA of environmental sample is used to identify diversity of microbial community present in the pollutant site. The product obtained from PCR is a mixture of genes obtained from the microbial community. It is a signature of from all microorganisms along with VBNC. Amplification with the PCR for the conserved genes of $16 \mathrm{~S}$ rRNA is found in all prokaryotes. They are conserved functionally in the microbial community [65]. Some of the conserved genes such as gyrase beta subunit $(\mathrm{gyr} B)$, RNA polymerase beta subunit $(r p o B)$, heat shock protein (hsp60), and recombinase A (recA) are applied to find the differentiation between the subpopulation of bacteria [54]. A marker sequence from the DNA of environmental samples is cloned and subjected to sequencing of gene fragments [120]. A sticky end (30-A) is added to the PCR product which can make ligation of plasmid vectors with an overhanging 30-T efficiently. The sequences obtained are compared with the known sequences available in databases (GenBank, Ribosomal Database Project, Green-genes, second genome) [24].

The cloning method was executed to investigate the dynamics of microbial populations in the deep subsurface of mining impacted soil in Homestake gold mine. In this work, the authors had analyzed 230 clone sequences that reveal only phylogenetic breadth inhabit particularly in the soil samples [121]. A combination of RT-PCR, Q-PCR, and clone library methods could analyze the microbial diversity found in the subsurface sediments of Hanford nuclear waste pollution site [87]. The authors have found 13 novel phylogenetic orders in 8000 sequences within $\delta$-proteobacteria, capable of metabolizing of heavy metals and radionuclides.

\section{Genetic Fingerprinting Technique}

The genetic fingerprinting technique is a high-throughput method dealing with random amplified polymorphic DNA (RAPD), denaturing or temperature gradient gel electrophoresis (DGGE/TGGE), amplified ribosomal DNA restriction analysis (ARDRA), terminal restriction fragment length polymorphism (T-RFLP), and rRNA intergenic spacer analysis (RISA).

DGGE methodology has implemented to the water and soil samples to assess the structure of the microbial ecology in the pollutant sites. Some researchers have used the DGGE technique in metal contaminated site to assess the soil microbial diversity. Based on their analysis, they concluded that pollutant sites are less abundant with respect to bacterial populations [32, 117]. Sulfate-reducing bacteria from contaminated petroleum hydrocarbons aquifer was examined by fluorescence in situ hybridization (FISH) technology [75, 117]. Recently, some research groups have isolated hydrocarbon degrading bacteria and diatoms from hydrocarbon-polluted sediment in coastal mudflats by reverse-transcribed bacterial $16 \mathrm{~S}$ rRNA technology [30]. The degradation of 2,4,6-trinitritoluene by some microorganisms ( $\gamma$ and $\beta$ Proteobacteria, and Clostridia species) was studied recently using DGGE technology $[21,45]$.

The microbial diversity was assessed by RAPD technique in the soil sample contaminated with pesticides (triazolone) and chemical fertilizers (ammonium bicarbonate) [183]. ARDRA technique provides very less information about the groups of microorganisms which are found in the polluted site. However, this method is very rapid and also suitable for assessing the microbial diversity with respect to changing 
Fig. 4 Profiling perspective for non-cultured microbial population in polluted sites

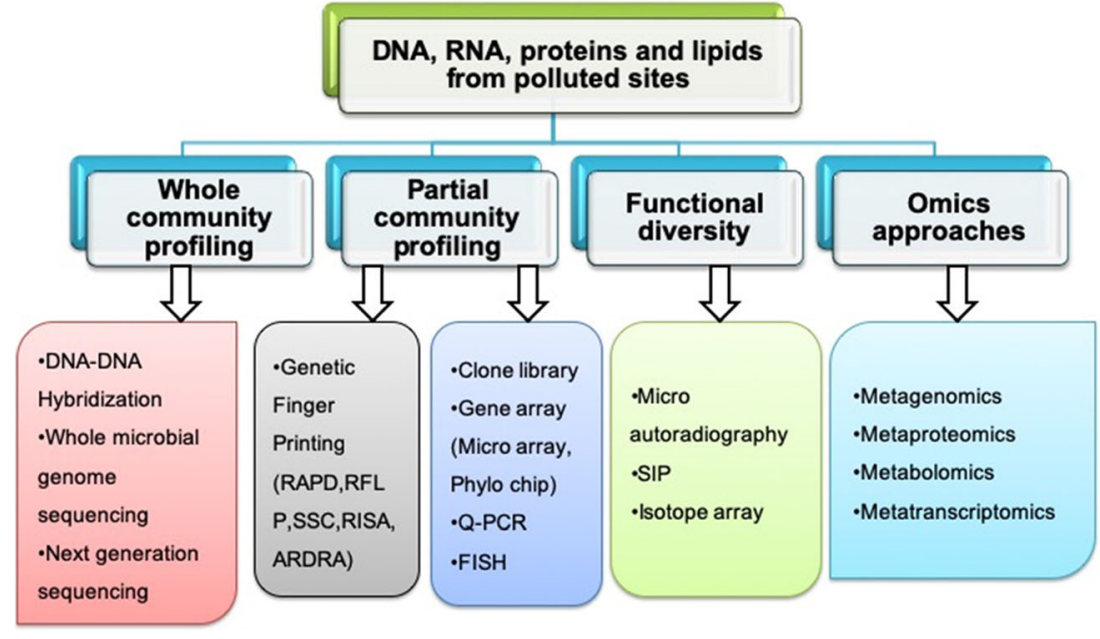

conditions of the environment. Based on the restriction profiles of clones, this technique can identify the unique clones and operated taxonomic units in environment-based clone libraries [21]. Several papers have been published in biodegradation of trichloroethane in a contaminated aquifer with the help of ARDRA technique [117, 172].

T-RFLP was developed to analyze the microbial communities with help of the clone library in a cost-effective manner [88]. An automated sequencer is used which can produce highly reproducible results for repeated samples. T-RFLP along with amplicon library was used by Allen et al. [6], to investigate the microbial community of methanotrophs inhabiting at the site of underground petroleum plume. Detection of a biodegrading hot spot was studied successfully by some researchers through T-RFLP technique in the site of tar oil-contaminated aquifer. The authors had also detected some of the toluene-degrading organisms from tar oilcontaminated aquifer [80]. T-RFLP technique was also helpful to analyze the diversity of microbial populations from soils contaminated with metals [150]. Microbial profiling of heavy metal contaminated soils was investigated using the same technique [37]. The degradation kinetics of polyaromatic hydrocarbons at low temperature was investigated by some microbial populations ( $\alpha, \beta$, and $\gamma$-proteobacteria) using RISA methodology [44].

\section{Functional Microbial Diversity}

Functional diversity approach is currently being used to investigate the composition of microbial community and activity during the biodegradation process in a pollutant site. In this context, various metagenomics approaches like DNA microarrays, Q-PCR, microbial lipid analysis, and fluorescence in situ hybridization (FISH) have been explored to investigate the microbial degradation processes. Some of the practical applications in microbial degradation of pollutants based upon the functional gene have been summarized in Table 1.
DNA Microarrays Microarray is otherwise called as "microchip." It is an emerging technology in the area of genetic research. It can provide a comprehensive view of microbial dynamics and their populations in pollutant samples [53]. The pollutants to be analyzed subjected to incubate in the presence of a radioactively labeled substrate before the hybridization methodology. This will be helpful to identify the basic character of microorganisms during the degradation of a specific pollutant.

Presently, "GeoChip" microarrays have come to picture which contain $83,99,250$ metric sequences covering approximately 1,52,414 genes responsible for enzymes required for resistance to heavy metals and pollutants degradation [18]. Another kind of microarray is also known as "PhyloChip" and is useful in the environmental biotechnology in the process of biodegradation for the phylogenetic analyses of bacterial communities efficiently and high-throughput manner [36].

Microbial Lipid Analysis Fatty acids present in the cell biomass with a constant proportion with cell biomass. Therefore, signature fatty acids exist in each microbial cell. This property helps the microbial community to be differentiated from the other groups.

The fatty acids were obtained by saponification and subjected to its derivatization producing an acid methyl ester (FAME). The signature obtained from the lipids has to compare with a reference FAME database. Banowetz et al. [12] had detected fatty acids with respect to microbial signatures with the help of multivariate statistical analyses. Analysis of soil microbial community structure by FAME profiles extracted from soils has found to be rapid and inexpensive nature. FAME analysis could successfully classify sediment soil and water samples with respect to microbial load [29, 132].

Quantitative Polymerase Chain Reaction This is an advanced technique used for quantification and detection of specific genes from DNA mixtures of environmental sample [58]. 
Table 1 Applications of various genome-based approaches

\begin{tabular}{|c|c|c|c|}
\hline Sr. No & Genome-based approach & Applications & Reference \\
\hline 1 & SOLiD & $\begin{array}{l}\text { - Phylogenetic diversity as well as metabolic activities of communities of } \\
\text { microorganisms in the Sargasso Sea } \\
\text { - Analysis of microbial population and dynamics from anammox wastewater } \\
\text { treatment plant }\end{array}$ & $\begin{array}{l}\cdot[189] \\
\cdot[126]\end{array}$ \\
\hline 2 & Metaproteomics & $\begin{array}{l}\text { Gene function and metabolic activity of acid mine drainage in microbial } \\
\text { biofilm }\end{array}$ & {$[137]$} \\
\hline 3 & Metabolomics & Detection and quantification of small molecules released into the environment & {$[4]$} \\
\hline 4 & Pyrosequencing & $\begin{array}{l}\text { - Detecting microbial communities along with functional genes from } \\
\text { tannery-based wastewater treatment plant } \\
\text { - Bacterial diversity from oil-contaminated sites } \\
\text { - Detection of microbial population from the wastewater treatment plants in } \\
\text { China }\end{array}$ & $\begin{array}{l}\cdot[170] \\
\cdot[113] \\
\cdot[63]\end{array}$ \\
\hline 5 & Nanopore Sequencing & $\begin{array}{l}\text { - Plasmids coding for carbapenemase was characterized in enterobacteria } \\
\text { which was isolated from the wastewater treatment plant }\end{array}$ & [91] \\
\hline 6 & (NGS) next-generation sequencing & $\begin{array}{l}\text { - Dynamics of microbial populations were evaluated in the wastewater } \\
\text { treatment plants } \\
\text { - Assessment of microbial communities from oil-contaminated sites in the } \\
\text { process of bioremediation of pollutants }\end{array}$ & $\begin{array}{l}\cdot[93] \\
\cdot[113]\end{array}$ \\
\hline
\end{tabular}

Some of the researchers have determined microbial diversity from wastewater samples by using quantitative polymerase chain reaction (Q-PCR) along with T-RFLP techniques [188]. In order to quantify and characterize the active microbial community found in naphthalene, degradation process was studied by some scientists implementing this technique. In order to quantify the soil microbes, several sets of primers were also designed through rapid Q-PCR technology [47]. The Q-PCR technique was also used by some researchers in order to quantify the bacterial community and its activity of uranium-contaminated sample through in situ bioremediation process [60].

Some of the key achievements like identification of potential bacterial species like methane oxidizers, sulfate reducers, and ammonia oxidizers were characterized successfully with the help of Q-PCR technique [48]. In addition to this, bioaugmentation of atrazine-contaminated soil was also investigated by some researchers by using Q-PCR methodology [182]. Some of the functional genes namely $\operatorname{trz} N$, atzB, and $a t z C$ responsible for degradation of atrazine were detected by the Q-PCR technology. A continuous increase in abundance of these genes during bioaugmentation process was also observed [182].

Fluorescence In situ Hybridization This methodology has been applied to explore bacterial communities and dynamics in the cultivated soils treated with s-Triazine [22]. In addition to this, it has also applied to investigate the simazine remediating microorganism in soil treated with s-Triazine [111].

The major limitations in fluorescence in situ hybridization (FISH) include background fluorescence, low signal intensity, and inaccessibility for the target. These limitations can be avoided by using various techniques like (a) brighter fluorochromes application, (b) treatment of chloramphenicol, and (c) amplification of signal with reporter enzymes [149]. A full-scale anaerobic sludge digester was experimented by some researchers to analyze functional community structures of bacteria and archaea with the help of FISH technology [83].

\section{Microbial Biosensor and Indicator-How They Respond to Pollution?}

Biosensors are integrated devices that detect and quantify presence of a given chemical substance. A typical biosensor recognizes a chemical or biological reaction and gives out a signal that is proportional to the quantity of the analyte present [19]. The analyte is biological in nature and the biochemical signal generated in the biosensor is converted to a readable format using a transducer. Microbial biosensors contain immobilized microorganisms (bio element) together with a transducer (electrical element). Microorganisms show the ability to detect a wide range of signals that result from proton concentration, gaseous uptake/release, emission or absorption of light, and so on that occur due to the interaction between the organism and the analyte [112].

Hasselbach et al. [59] had utilized Hylocomium splendens to investigate its potential as a natural indicator for the pollution of heavy metals in northwestern Alaska. It was found that bacterium Vogesella indigofera reacts to heavy metals imitatively. In the absence of metal, it produces blue pigmentation which marks the morphological change that observed. Under hexavalent $\mathrm{Cr}$, the production of pigment is stopped. This pigment synthesis is due to the relationship between the quantification of $\mathrm{Cr}$ and the blue pigment generated by the bacterium $[33,112]$. Recently, a recombinant E.coli strain has been 
developed based on the fluorescent protein expression. When the pollutants like heavy metals were exposed to these recombinant cells, the fluorescent proteins were expressed that symbolized the amount of heavy metals in wastewater samples [123]. Using silver nanoparticles, simultaneous quantitative analysis of multiple heavy metals in water samples was analyzed with multidimensional apta-sensors [141]. Recently, microbial fuel cell (MFC) was applied to detect the heavy metals present in the wastewater. In this approach, changes in voltage signal were measured through the activity of immobilized bacteria. These biosensors were introduced as a quick sensor to detect the low concentration of $\mathrm{Cu}^{2+}, \mathrm{Zn}^{2+}$, and $\mathrm{Cr}^{6+}$ in industrial wastewater [89]. Recently, some researchers have developed an MFC-based biosensor for toxicity monitoring of the heavy metals on microbial community for a prolonged time in mining rock drainage [3]. Several reports have also introduced microfluidic-based devices which are utilizing a field-effect transistor (FET) as a signal-transducer [92, 169].

An effective system with bacterial biosensors transformed with pLUX plasmids (LuxCDABE) that is having the ability for detection of COD in pollutant water by measuring changes in the activity of bioluminescence [107]. Microorganisms usually consist of reporter genes that are constitutively upregulated by a promoter, resulting in the production of reporter proteins which act as the signal. In a recent study, a multiplex $\mathrm{Cd}$ biosensor has been developed by research for detection of Psedomonas putida 06909 [79].

There are some limitations which have been noticed in case of biosensors. The response time is found to be prolonged sometimes. In some cases, it is difficult to maintain cell viability and activity. When engineered microbes are used, the genetic stability may be found to be less durable. The diffusion rate of substrates and products across the cell membrane into cells is found slow. Environmental factors such as temperature and $\mathrm{pH}$, as well as nutrient availability, also reduce the functionality.

\section{Role of Microbial Enzymes in the Remediation of Pollutants}

Various groups of microbial enzymes viz. oxidoreductases (oxygenases, monooxygenases, and dioxygenases), laccases, peroxidases, and lipases are responsible for the degradation of the major pollutants. Some of the reported microbial enzymes and their action to remediate the target pollutants have been summarized in Table 2. Oxidoreductases catalyze the oxidation of pollutants like aliphatic olefins and chlorinated biphenyls adding the molecules of oxygen [25]. Laccase breaks the ring of aromatic compounds and does the reduction of molecular oxygen in water [135]. Wastewater treatment and polyaromatic hydrocarbon degradation are mediated by the catalytic activity of lipases [99]. Hydrolysis of phosphotriesters groups of organophosphorus pesticides is catalyzed by phosphotriesterases [130]. Carboxylesterases hydrolyzes carboxyl ester bond present in synthetic pesticides such as organophosphates [138]. The degradation kinetics for selected pollutants obtained from reported literature has been summarized in Table 3 .

\section{Improvement of Microbial Strains by Genetic Manipulation for Enhanced Biodegradation}

Various genes with the ability for degrading different groups of pollutants have been discovered from different microorganisms (as summarized in Table 4). They have provided the possibility of constructing genetically engineered microorganisms for efficient pollutants removal from the environment [159]. The genes obtained from microorganisms have been tailored to create new metabolic pathways. This leads to enhance the biodegradation mechanisms for the specific pollutants. Two pesticides degrading genes $\operatorname{lin} A$ for organochlorine and $m p d$ for organophosphates were integrated with the plasmid of E. coli to make an engineered strain which simultaneously degrades these pesticides [184]. In order to enhance the biodegradation of fenpropathrin, $p y t H$ gene (responsible for the synthesis of pyrethroid hydrolase) was isolated from Sphingobium sp. JZ-2. Later, this gene pytH was overexpressed in Sphingobium sp. BA3 helps in the construction of a recombinant strain having more biodegrading potential [41].

The enzyme azobenzene reductase or azoreductase is responsible for the removal of azo dyes from the wastewater released as industrial effluents. The azoreductase has been isolated from various microorganisms viz. Xenophilus azovogarls KF46F, Enterobacter agglomerans, and Enterococcus faecalis [133]. Recently, some researchers have isolated gene $f d h$ (coded for formate dehydrogenase) and $a z o A$ (coded for azoreductase) from Mycobacterium vaccae and Enterococcus sp. L2 respectively in order to decolorize the industrial colored effluents [122].

Heavy metals can cause some physiological and genotoxic effects on different groups of microorganisms if it is exceeding a certain concentration. In order to enhance biodegradation of cadmium $\left(\mathrm{Cd}^{2+}\right)$, metallothionein gene was isolated from yeast and expressed in $E$. coli to develop a recombinant strain. This resulted strain possessed 15-20 times higher cadmium ion $\left(\mathrm{Cd}^{2+}\right)$-enrichment capacity as compared to the parent strain [119].

A gene (alkB) coding for alkane monooxygenase was manipulated to the non-alkane degrading strain of Streptomyces coelicolor M145 strain, which could enhance the degradation ability [50]. The $x y l E$ is a gene which codes for catechol 2, 3dioxygenase and essential for the biodegradation of aromatic hydrocarbon compounds. This particular gene was cloned 
Table 2 Microbial enzymes and their action to remediate the target pollutants

\begin{tabular}{lllll}
\hline S.L No & Name of the enzymes & Source organisms & Target pollutants & Reference \\
\hline 1 & Urease & Bacillus megaterium strain SZK-5 & Hydrolyzed polyacrylamide (HPAM) & {$[$ 142] } \\
2 & Alkane hydroxylase, lipase, esterase & Alcanivorax borkumensis & Hexadecane, motor oil BTEX & Polyvinyl alcohol (PVA) \\
3 & PVAase & Bacillus niacini & Hydrocarbons & {$[148]$} \\
4 & Lipase, laccase, and peroxidases & Mucor circinelloides & Polyethylene & {$[61]$} \\
5 & Laccase & Rhodococcus ruber & Dimethyl phthalate ester \\
6 & Phthalate dioxygenase & Variovorax sp. BS1 & Poly (DL-lactic acid) \\
7 & Crude enzyme extract & Actinomadura keratinilytica strain T16-1 & Malachite Green dye \\
8 & Crude enzyme extract & Bacillus cereus & Acrylamide from Industrial waste water \\
9 & Acrylamidase & Cupriavidus oxalaticus ICTDB921 & Pyrene & {$[16]$} \\
10 & Monooxygenase Diooxygenase & Pseudomonas sp. ASP-53 & 4-chlorophenol \\
11 & Crude enzyme extract & Fusarium sp. & {$[10]$} \\
\hline
\end{tabular}

from plasmid DNA of Pseudomonas putida BNF1 and inserted to the alkanes degrading strain Acinetobacter sp. BS3 in order to enhance its efficiency in the process of bioremediation [177]. The 26 number of bacterial strains belonging to the genera Sphingobium and Sphingomonas were sequenced completely to investigate the biodegradation of

Table 3 Summary of degradation kinetics for selected pollutants obtained from reported literatures

\begin{tabular}{|c|c|c|c|c|c|}
\hline $\begin{array}{l}\text { S.L } \\
\text { No. }\end{array}$ & Microorganism(s) used & Target Pollutant & $\begin{array}{l}\text { Kinetic model implementation and } \\
\text { parameters }\end{array}$ & Specific remarks & Reference \\
\hline 1 & $\begin{array}{l}\text { Immobilized cells of } \\
\text { Halomonas and } \\
\text { Aneurinibacillus }\end{array}$ & Diesel & $\begin{array}{l}\text { Monod model was fitted. } \\
\cdot \mathrm{V}_{\max }=1.84 \mathrm{~d}^{-1} \\
\cdot \mathrm{K}_{\mathrm{s}}=3.23 \mathrm{~g} / \mathrm{L}\end{array}$ & $\begin{array}{l}\text { - The rate of degradation for the } \\
\text { immobilized cells in straw-alginate } \\
\text { beads was found to be } 68.68 \% \text {. }\end{array}$ & {$[179]$} \\
\hline 2 & $\begin{array}{l}\text { Citrobacter sp. NVK-2, } \\
\text { Providencia } \text { sp. NVK-2A, } \\
\text { Citrobacter sp. NVK-6 }\end{array}$ & $\begin{array}{l}\text { Selenite contaminated } \\
\text { water }\end{array}$ & $\begin{array}{l}\text { NVK-2 strain: } \\
\text { - } \mathrm{V}_{\max }=58.82 \mu \mathrm{Mh}^{-1} \\
\cdot \mathrm{K}_{\mathrm{m}}=3737.12 \mu \mathrm{M} \\
\text { NVK-2A strain: } \\
\text { - } \mathrm{V}_{\max }=9.26 \mu \mathrm{Mh}^{-1} \\
\cdot \mathrm{K}_{\mathrm{m}}=3044.73 \mu \mathrm{M} \\
\mathrm{NVK}-6 \text { strain: } \\
\cdot \mathrm{V}_{\max }=19.23 \mu \mathrm{Mh}^{-1} \\
\cdot \mathrm{K}_{\mathrm{m}}=1300.17 \mu \mathrm{M}\end{array}$ & $\begin{array}{l}\text { - Citrobacter sp. NVK-2 was found to } \\
\text { be potential bacterium for } \\
\text { biodegradation of high Se (IV) } \\
\text { concentration as having highest } \\
\mathrm{V}_{\max } \text { and } \mathrm{K}_{\mathrm{m}} \text { values }\end{array}$ & {$[152]$} \\
\hline 3 & $\begin{array}{l}\text { Pseudomonas putida strain } \\
\quad \text { G3 }\end{array}$ & Butachlor & $\begin{array}{l}\text { Haldane model was fitted } \\
-\mu_{\mathrm{m}}=2.74 \mathrm{mg} / \mathrm{Lh}^{-1} \\
\text { - } \mathrm{K}_{\mathrm{s}}=66.393 \mathrm{mg} / \mathrm{L} \\
\cdot \mathrm{K}_{\mathrm{i}}=1214.33 \mathrm{mg} / \mathrm{L}\end{array}$ & $\begin{array}{l}\text { - The Pseudomonas putida } \mathrm{G} 3 \text { can } \\
\text { degrade } 100 \% \text { of } 700 \mathrm{mg} / \mathrm{L} \text { - } \\
\text { butachlor in } 15 \text { days }\end{array}$ & {$[102]$} \\
\hline 4 & $\begin{array}{l}\text { Mixed cultures of } \\
\text { Pseudomonas and } \\
\text { Rhodococcus }\end{array}$ & $\begin{array}{l}\text { Atrazine, } \\
\text { 2,4-dichlorophenoxy } \\
\quad \text { acetic acid } \\
(2,4-D)\end{array}$ & $\begin{array}{l}\text { Monod model was fitted. } \\
\text { For Atrazine: } \\
\text { - } \mu_{\mathrm{m}}=0.011 \mathrm{~L} / \mathrm{d} \\
\text { - } \mathrm{Y}=0.53 \mathrm{~g} / \mathrm{g} \\
\text { For } 2,4-\mathrm{D}: \\
\text { - } \mu_{\mathrm{m}}=0.071 \mathrm{~L} / \mathrm{d} \\
\text { - } \mathrm{Y}=0.44 \mathrm{~g} / \mathrm{g}\end{array}$ & $\begin{array}{l}\text { - The 2,4-D biodegradation was } 6 \\
\text { times higher than that of atrazine }\end{array}$ & {$[17]$} \\
\hline 5 & Phomopsis sp. & Anthraquinone dye & $\begin{array}{l}\text { Lineweaver-Burk model was fitted } \\
\cdot \mathrm{V}_{\max }=8.06 \mathrm{mgL}^{-1} \mathrm{~h}^{-1} \\
\cdot \mathrm{K}_{\mathrm{m}}=62.43 \mathrm{mgL}^{-1}\end{array}$ & $\begin{array}{l}\text { - The degradation of the dye was due to } \\
\text { production of laccase enzyme which } \\
\text { can decolorized } 200 \mathrm{mg} \mathrm{L}^{-1} \text { of dye } \\
\text { within } 20 \mathrm{~min}\end{array}$ & {$[74]$} \\
\hline 6 & $\begin{array}{l}\text { Cupriavidus } \\
\text { oxalaticus ICTDB } 921\end{array}$ & $\begin{array}{l}\text { Acrylamide from } \\
\text { industrial waste }\end{array}$ & $\begin{array}{l}\text { Haldane model was fitted } \\
\cdot \mathrm{V}_{\max }=2990 \mathrm{mM} / \mathrm{min} \\
\cdot \mathrm{K}_{\mathrm{m}}=62.02 \mathrm{mM}\end{array}$ & $\begin{array}{l}\text { - The degradation of the dye was due to } \\
\text { production of acrylamidase enzyme } \\
\text { synthesized by Cupriavidus } \\
\text { oxalaticus }\end{array}$ & {$[15]$} \\
\hline 7 & Fusarium sp. HJ01 & 4-chlorophenol & $\begin{array}{l}\text { The Michaelis-Menten equation } \\
\text { was fitted } \\
\text { - } \mathrm{V}_{\max }=11.507 \mu \mathrm{Mh}^{-1} \\
\text { - } \mathrm{K}_{\mathrm{m}}=0.772 \mu \mathrm{M}\end{array}$ & $\begin{array}{l}\text { - The biosynthesis of chlorocatechol } \\
\text { 1,2-dioxygenase enzyme could able } \\
\text { to degrade the 4-chlorophenol }\end{array}$ & [84] \\
\hline
\end{tabular}


Table 4 Genes, microorganisms, and their biodegradation ability for different groups of pollutants

\begin{tabular}{|c|c|c|c|c|}
\hline Sr. No. & Source organism & Name of the gene & Targeted pollutant & Reference \\
\hline 1 & Sphingobium wenxiniae JZ-1 & $p b a A 1 A 2 B C$ & 3-Phenoxybenzoate & {$[28]$} \\
\hline 2 & Acinetobacter sp. $B S 3-C 23 O$ & $x y l E$ & n-Alkanes/aromatic hydrocarbons & {$[177]$} \\
\hline 3 & Sphingomonas sp. DC-6 & $C n d A$ & Acetochlor & {$[27]$} \\
\hline 4 & Pseudomonas pseudoalcaligenes & ophc2 & Methyl parathion & {$[55]$} \\
\hline 5 & Sphingobium quisquiliarum $D C-2$ & $\mathrm{cmeH}$ & Acetochlor & {$[85]$} \\
\hline 6 & Pseudomonas sp. CGMCC2953-pK & $x y l E$ & PAHs & [192] \\
\hline 7 & Hansschlegelia zhihuaiae S113 & SulE & Sulfonylurea herbicide & {$[57]$} \\
\hline 8 & Streptomyces coelicolor M145-AH & alkB & n-Alkanes & {$[50]$} \\
\hline 9 & Burkholderia cepacia & $m p h$ & Organophosphorus & {$[43]$} \\
\hline 10 & Rhodococcus sp. T1 & feh & Fenoxaprop-ethyl & {$[62]$} \\
\hline 11 & Sphingobium sp. JZ-2 & pyt $H$ & Fenpropathrin & {$[41]$} \\
\hline 12 & Comamonas testosteroni SB3 & $d s R e d$ & 3-Chloroaniline & {$[14]$} \\
\hline 13 & Escherichia coli JM109 & Azo reductase gene & Azo dyes, C.I. Direct Blue 71 & {$[71]$} \\
\hline
\end{tabular}

PAH. They have characterized the gene cluster of $a x y l$ gene in six PAHs-degrading strains [191]. The examples of various genes, source organisms, and their ability towards degrading pollutants have been summarized in Table 4 .

\section{Future Perspectives and Concluding Remarks}

The environment-friendly and low-cost bioremediation approach is considered as one of the best ways for cleaning up the polluted area. Moreover, the pollutant's degradation rate, reaction model, degradation pathways, degradation mechanisms, and physiological factors affecting the degradation should be considered for the effective bioremediation process. The degradation strategy of many pollutants along with causative genes and enzymes is also not known for many industrial pollutants. In addition to this, degraded pollutant may be found to be more persistent and hazardous than the initial pollutants. This is a major challenge and the researchers are working to overcome these problems. The concept of "nanobioremediation" has just emerged, for removing heavy metals and organic contaminants from wastewater and soil using nanoparticles synthesized by particular plants, bacteria, algae, and fungi under controlled conditions [180].

The genetic flexibility along with metabolic versatility is the key asset that opens a way for microorganisms to withstand the presence of pollutants. Microbial eco-toxicological tools not only enable to determine the concentration of pollutants but also assess the toxic effects of these pollutants at different biological levels such as genomic, metabolic, and community levels. This can be concluded that biosensors derived from microorganisms have achieved the attention of researchers because of its high specificity towards target pollutants and non-invasive nature. The degradation of environmental pollutants by the application of microorganisms is an emerging technology; however, various genetic approaches to optimize growth conditions, metabolic pathways, and enzyme production are highly useful to fulfill the demand.

Acknowledgments Bishwambhar Mishra acknowledges the Centurion University, Odisha for providing infrastructure and smart digital library facilities.

\section{Compliance with Ethical Standards}

Conflict of Interest The authors declare that they have no conflict of interest.

Human and Animal Rights and Informed Consent This article does not contain any studies with human or animal subjects performed by any of the authors.

\section{References}

1. Abbasian F, Lockington R, Mallavarapu M, Naidu R. A comprehensive review of aliphatic hydrocarbon biodegradation by bacteria. Appl Biochem Biotechnol. 2015;176(3):670-99.

2. Ádám N, Monika JF, Leszek M, Barbara K, Jan K, Danuta SD, et al. Distribution of coal and coal combustion related organic pollutants in the environment of the Upper Silesian Industrial Region. Sci Total Environ. 2018;628-629:1462-88.

3. Ademola A, Vijaya R, Boris T. On-line monitoring of heavy metals-related toxicity with a microbial fuel cell biosensor. Biosens Bioelectron. 2019;132:382-90.

4. Aguiar-Pulido V, Huang W, Suarez-Ulloa V, Cickovski T, Mathee K, Narasimhan G. Metagenomics, metatranscriptomics, and metabolomics approaches for microbiome analysis. Evol Bioinformatics Online. 2016;12(Suppl 1):5-16.

5. Ajeng AS, Anis K, Sanro T, Yanni S, Haznan A. Mechanisms and optimization of oil palm empty fruit bunch as a pre-grown source for white-rot fungus to degrade DDT. J Environ Chem Eng. 2014;2:1410-5.

6. Allen JP, Atekwana EA, Duris JW, Werkema DD, Rossbach S. The microbial community structure in petroleum-contaminated 
sediments corresponds to geophysical signatures. Appl Environ Microbiol. 2007;73:2860-70.

7. Amatussalam A, Abubacker MN, Rajendran RB. In situ Carica papaya stem matrix and Fusarium oxysporum (NCBT-156) mediated bioremediation of chromium. Indian J Exp Biol. 2011;49: 925-31.

8. Aravindhan R, Nair BU. Biological removal of carcinogenic $\mathrm{Cr}$ (VI) using mixed Pseudomonas strains. Bioresour Technol. 2006;11:11-7.

9. Arya R, Sharma AK. Bioremediation of carbendazim, a benzimidazole fungicide using Brevibacillus borstelensis and Streptomyces albogriseolus together. Curr Pharm Biotechnol. 2015;17:185-9.

10. Ashis K, Mukherjee PB, Bhim BB, Abhishek C, Bhargab K. A comparative intracellular proteomic profiling of Pseudomonas aeruginosa strain ASP-53 grown on pyrene or glucose as sole source of carbon and identification of some key enzymes of pyrene biodegradation pathway. J Proteome. 2017;167:25-35.

11. Azarbad H, Niklińska M, Nikiel K, van Straalen NM, Röling WFM. Functional and compositional responses in soil microbial communities along two metal pollution gradients: does the level of historical pollution affect resistance against secondary stress. Biol Fertil Soils. 2015;51:879-90.

12. Banowetz GM, Gerald WW, Karen PD, Mark DA, Ann CK, Stephen MG, et al. Fatty acid methyl ester analysis to identify sources of soil in surface water. J Environ Qual. 2006;35:133-40.

13. Barra Caracciolo A, Topp E, Grenni P. Pharmaceuticals in the environment: biodegradation and effects on natural microbial communities. A review. J Pharm Biomed Anal. 2015;106:25-36.

14. Bathe S, Schwarzenbeck N, Hausner M. Bioaugmentation of activated sludge towards 3-chloroaniline removal with a mixed bacterial population carrying a degradative plasmid. Bioresour Technol. 2009;100:2902-9.

15. Bedade DK, Muley AB, Singhal RS. Magnetic cross-linked enzyme aggregates of acrylamidase from Cupriavidus oxalaticus ICTDB921 for biodegradation of acrylamide from industrial waste water. Bioresour Technol. 2018;272:137-45.

16. Bedade DK, Muley AB, Singhal RS. Magnetic cross-linked enzyme aggregates of acrylamidase from Cupriavidus oxalaticus ICTDB921 for biodegradation of acrylamide from industrial waste water. Bioresour Technol. 2019;272:137-45.

17. Belen C, José V, Francisco J, Fernandez M. Modelling aerobic biodegradation of atrazine and 2,4-dichlorophenoxy acetic acid by mixed-cultures. Bioresour Technol. 2017;243:1044-50.

18. Bernard EI, Stanley IRO, Grace OI, Ebere PA, Abraham OA, Ibe KE. Toxicity and bioremediation of heavy metals contaminated ecosystem from tannery wastewater: a review. 2018; https://doi. org $/ 10.1155 / 2018 / 2568038$

19. Bhalla N, Jolly P, Formisano N, Estrela P. Introduction to biosensors. Essays Biochem. 2016;60:1-8.

20. Bhatt M, Cajthaml T, Šašek V. Mycoremediation of PAHcontaminated soil. Folia Microbiol. 2002;47:255-8.

21. Bhunia B, Prasad Uday US, Oinam G, Mondal A, Bandyopadhyay TK, Tiwari ON. Characterization, genetic regulation, and production of cyanobacterial exopolysaccharides and its applicability for heavy metal removal. Carbohydr Polym. 2018; 179:228-43

22. Caracciolo AB, Paola B, Paola G. Fluorescence in situ hybridization in soil and water ecosystems: a useful method for studying the effect of xenobiotics on bacterial community structure. Toxicol Environ Chem. 2010;92:567-79.

23. Carmen T, Andreea-Florina G, George B, Silvia F. Emerging pollutants removal through advanced drinking water treatment: a review on processes and environmental performances assessment. J Clean Prod. 2018;197:1210-21.

24. Chakraborty J, Das S. Characterization and cadmium resistant gene expression of the biofilm-forming marine bacterium
Pseudomonas aeruginosa JP-11. Environ Sci Pollut Res. 2014;21:14188-201.

25. Chakraborty J, Jana T, Saha S, Dutta TK. Ring-hydroxylating oxygenase database: a database of bacterial aromatic ringhydroxylating oxygenases in the management of bioremediation and biocatalysis of aromatic compounds. Environ Microbiol Rep. 2014;6:519-23.

26. Chekroun KB, Sánchez E, Baghour M. The role of algae in bioremediation of organic pollutants. Int Res J Public Environ Health. 2014;1:19-32.

27. Chen Q, Wang CH, Deng SK, Wu YD, Li Y, Yao L, et al. Novel three-component Rieske non-heme iron oxygenase system catalyzing the Ndealkylation of chloroacetanilide herbicides in sphingomonads DC-6 and DC-2. Appl Environ Microbiol. 2014;420:5078-85.

28. Cheng M, Chen K, Guo S, Huang X, He J, Li S, et al. PbaR, an IclR-family transcriptional activator for the regulation of the 3phenoxybenzoate $1^{\prime}, 2^{\prime}$ - dioxygenase gene cluster in Sphingobium wenxiniae JZ-1T. Appl Environ Microbiol. 2015;81(23):8084-92.

29. Clarissa W, Peet JJR, Sarina C. Can a metabolomics-based approach be used as alternative to analyse fatty acid methyl esters from soil microbial communities? Soil Biol Biochem. 2016;103: 417-28.

30. Coulon F, Chronopoulou PM, Fahy A, Parsse S, Goni-Urriza M, Peperzak L. Central role of dynamic tidal biofilms dominated by aerobic hydrocarbonoclastic bacteria and diatoms in the biodegradation of hydrocarbons in coastal mudflats. Appl Environ Microbiol. 2012;78:3638-48.

31. Cuozzo SA, Fuentes MS, Bourguignon N, Benimeli CS, Amoroso MJ. Chlordane biodegradation under aerobic conditions by indigenous Streptomyces strains. Int Biodeterior Biodegradation. 2012;66:19-24.

32. Czaplicki LM, Gunsch CK. Reflection on molecular approaches influencing state-of-the-art bioremediation design: culturing to microbial community fingerprinting to omics. J Environ Eng. 2016;142:03116002. https://doi.org/10.1061/(ASCE)EE.19437870.0001141

33. Dai C, Choi S. Technology and applications of microbial biosensor. Open J Appl Biosens. 2013;2:83-93.

34. Danni J, Piao X, Han W, Guangming Z, Danlian H, Ming C, et al. Strategies to improve metal organic frameworks photocatalyst's performance for the degradation of organic pollutants. Coord Chem Rev. 2018;376:449-66.

35. Dave S, Damani M, Tipre D. Copper remediation by Eichhornia spp. and sulphate- reducing bacteria. J Hazard Mater. 2010;173: 231-5.

36. DeAngelis KM, Cindy HW, Harry RB, Eoin LB, Romy C, Todd ZD, et al. PCR amplification-independent methods for detection of microbial communities by the high-density microarray PhyloChip. Appl Environ Microbiol. 2011;77:6313-22.

37. Dhiraj KC, Jaisoo K. New insights into bioremediation strategies for oil-contaminated soil in cold environments. Int Biodeterior Biodegradation. 2019;142:58-72.

38. Diaz E, Jimenez JI, Nogales J. Aerobic degradation of aromatic compounds. Curr Opin Biotechnol. 2013;24:431-42.

39. Diepens NJ, Arts GHP, Brock TCM, Smidt H, Van Den Brink PJ, Van Den Heuvel-Greve MJ, et al. Sediment toxicity testing of organic chemicals in the context of prospective risk assessment: a review. Crit Rev Environ Sci Technol. 2014;44:255-302.

40. Dosnon-Olette R, Trotel-Aziz P, Couderchet M, Eullaffroy P. Fungicides and herbicide removal in Scenedesmus cell suspensions. Chemosphere. 2010;79:117-23.

41. Duan XQ, Zheng JW, Zhang J, Hang BJ, He J, Li SP. Characteristics of a 3-phenoxybenzoic acid degrading- 
bacterium and the construction of a engineering bacterium. Huan Jing Ke Xue. 2011;32:240-6.

42. Duran R, Bielen A, Paradžik T, Claire G, Emina P, Christine C, et al. Exploring Actinobacteria assemblages in coastal marine sediments under contrasted human influences in the West Istria Sea, Croatia. Environ Sci Pollut Res. 2015;22:15215-29.

43. Ekkhunnatham A, Jongsareejit B, Yamkunthong W, Wichitwechkarn J. Purification and characterization of methyl parathion hydrolase from Burkholderia cepacia capable of degrading organophosphate insecticides. World J Microbiol Biotechnol. 2012;28:1739-46.

44. Eriksson M, Sodersten E, Yu Z, Dalhammar G, Mohn WW. Degradation of polycyclic aromatic hydrocarbons at low temperature under aerobic and nitrate reducing conditions in enrichment cultures from northern soils. Appl Environ Microbiol. 2003;69: 275-84.

45. Fahrenfeld N, Zoeckler J, Widdowson M, Pruden A. Effect of biostimulants on 2,4,6-trinitrotoluene (TNT) degradation and bacterial community composition in contaminated aquifer sediment enrichments. Biodegradation. 2013;24:179-90.

46. Farshid G, Mahsa M. Application of peroxymonosulfate and its activation methods for degradation of environmental organic pollutants: review. Chem Eng J. 2017;310:41-62.

47. Fierer N, Jackson JA, Vilgalys R, Jackson RB. Assessment of soil microbial community structure by use of taxon-specific quantitative PCR assays. Appl Environ Microbiol. 2005;71:4117-20.

48. Foti R, Gnan S, Cornacchia D, Dileep V, Bulut-Karslioglu A, Diehl S, et al. Nuclear architecture organized by Rif1 underpins the replication-timing program. Mol Cell. 2016;61:260-73.

49. Fuchs G, Boll M, Heider J. Microbial degradation of aromatic compounds - from one strategy to four. Nat Rev Microbiol. 2011;9:803-16.

50. Gallo G, Piccolo LL, Renzone G, La Rosa R, Scaloni A, Quatrini $\mathrm{P}$, et al. Differential proteomic analysis of an engineered Streptomyces coelicolor strain reveals metabolic pathways supporting growth on $\mathrm{n}$-hexadecane. Appl Microbiol Biotechnol. 2012;94:1289-301.

51. Ganiyu OO, Keisuke M, Yi H, Mei-Fang C, Matthew OI, Olukayode OA, et al. Biotechnological remedies for the estuarine environment polluted with heavy metals and persistent organic pollutants. Int Biodeterior Biodegrad. 2017;119:614-25.

52. Garg UK, Kaur MP, Garg VK, Sud D. Removal of hexavalent $\mathrm{Cr}$ from aqueous solutions by agricultural waste biomass. J Hazard Mater. 2007;140:60-8.

53. Gentry TJ, Wickham GS, Schadt CW, He Z, Zhou J. Microarray applications in microbial ecology research. Microb Ecol. 2006;52: 159-75.

54. Ghebremedhin B, Layer F, Konig W, Konig B. Genetic classification and distinguishing of Staphylococcus species based on different partial gap, 16 rRNA, hsp60, rpoB, sodA, and tuf gene sequences. J Clin Microbiol. 2008;46:1019-25.

55. Gotthard G, Hiblot J, Gonzalez D, Elias M, Chabriere E. Structural and enzymatic characterization of the phosphotriesterase OPHC2 from Pseudomonas pseudoalcaligenes. PLoS One. 2013;8(11):e77995. https://doi. org/10.1371/journal.pone.0077995.

56. Gupta G, Chandra A, Varjani SJ, Banerjee C, Kumar V. Role of biosurfactants in enhancing the microbial degradation of pyrene. In: Varjani SJ, Agarwal AK, Gnansounou E, Gurunathan B, editors. Bioremediation: applications for environmental protection and management. Singapore: Springer Nature; 2018. p. 375-86.

57. Hang BJ, Hong Q, Xie XT, Huang X, Wang CH, He J, et al. SulE, a sulfonylurea herbicide de-esterification esterase from Hansschlegelia zhihuaiae S113. Appl Environ Microbiol. 2012;78:1962-8.
58. Harms G, Layton AC, Dionisi HM, Gregory IR, Garrett VM, Hawkins SA, et al. Real-time PCR quantification of nitrifying bacteria in a municipal wastewater treatment plant. Environ Sci Technol. 2003;37:343-51.

59. Hasselbach L, Ver Hoef J, Ford J, Neitlich P, Crecelius E, Berryman S, et al. Spatial patterns of cadmium and lead deposition on and adjacent to National Park Service lands in the vicinity of Red Dog Mine, Alaska. Sci Total Environ. 2005;348:211-30.

60. Holmes DE, Giloteaux L, Williams KH, Wrighton KC, Wilkins MJ, Thompson CA, et al. Enrichment of specific protozoan populations during in-situ bioremediation of uranium-contaminated groundwater. ISME J. 2013;7:1286-98.

61. Hongjie B, Mengfei C, Huan W, Zhilei T, Shiru J, Jiandong C. Biodegradation of polyvinyl alcohol using cross-linked enzyme aggregates of degrading enzymes from Bacillus niacini. Int Biodeterior Biodegradation. 2019;124:10-6.

62. Hou Y, Tao J, Shen W, Liu J, Li J, Li Y, et al. Isolation of the fenoxaprop-ethyl (FE)-degrading bacterium Rhodococcus sp. T1 and cloning of FE hydrolase gene feh. FEMS Microbiol Lett. 2011;323:196-203.

63. Hu M, Wang X, Wen X. Microbial community structures in different wastewater treatment plants as revealed by $454-$ pyrosequencing analysis. Bioresour Technol. 2012;117:72-9.

64. Huang F, Dang Z, Guo CL, Lu GN, Gu RR, Liu HJ, et al. Biosorption of Cd (II) by live and dead cells of Bacillus cereus RC-1 isolated from cadmium contaminated soil. Colloids Surf B: Biointerfaces. 2013;107:11-8.

65. Hugenholtz P. Exploring prokaryotic diversity in the genomic era. Genome Biol. 2002;3:reviews0003.1-8 (Last accessed: 01.06.2019).

66. Hui Q, Shaowei W, Huitao L, Yuan G, Tingting W, Yongshun H. Synthesis of an organic-inorganic polypyrrole/titanium (IV) biphosphate hybrid for Cr (VI) removal. J Mol Liq. 2016;215: 402-9.

67. Javadian H. Application of kinetic, isotherm and thermodynamic models for the adsorption of Co(II) ions on polyaniline/ polypyrrole copolymer nanofibers from aqueous solution. J Ind Eng Chem. 2014;20:4233-41.

68. Jean MCD, Laura DM, Rafael N, Rogelio N, Esperanza R. Enhancing pesticide degradation using indigenous microorganisms isolated under high pesticide load in bioremediation systems with vermicomposts. Bioresour Technol. 2016;214:234-41.

69. Jeevanantham S, Saravanan A, Hemavathy RV, Senthil KP, Yaashikaa PR, Yuvaraj D. Removal of toxic pollutants from water environment by phytoremediation: a survey on application and future prospects. Environ Technol Innov. 2019;13:264-76.

70. Jiao S, Zhang Z, Yang F, Lin Y, Chen W, Wei G. Temporal dynamics of microbial communities in microcosms in response to pollutants. Mol Ecol. 2016. https://doi.org/10.1111/mec.13978.

71. Jin R, Yang H, Zhang A, Wang J, Liu G. Bioaugmentation on decolorization of C.I. direct blue 71 using genetically engineered strain Escherichia coli JM109 ( $p G E X-A Z R)$. J Hazard Mater. 2009; 163:1123-8.

72. Jing W, Wei LO, Jie HH, Ghim WH. Inorganic-organic hybrid membranes for photocatalytic hydrogen generation and volatile organic compound degradation. Procedia Eng. 2017;215:202-10.

73. Jing F, Hongxiu L, Hongzhi Z, Minghung W, Shunqing X, Zongwei C. Association of prenatal exposure to organochlorine pesticides and birth size. Sci Total Environ. 2019;654:678-83.

74. Kavitha KN, Ganesh S, Ananda K. Enhanced biodegradation and kinetics of anthraquinone dye by laccase from an electron beam irradiated endophytic fungus. Int Biodeterior Biodegradation. 2018;132:241-50.

75. Kleikemper J, Schroth MH, Sigler WV, Schmucki M, Bernasconi SM, Zeyer J. Activity and diversity of sulfate-reducing bacteria in 
a petroleum hydrocarbon contaminated aquifer. Appl Environ Microbiol. 2002;68:1516-23.

76. Kong D, MacLeod M, Li Z, Cousins IT. Effects of input uncertainty and variability on the modelled environmental fate of organic pollutants under global climate change scenarios. Chemosphere. 2013;93:2086-93.

77. Kumari V, Yadav A, Haq I, Kumar S, Bharagava RN, Singh SK, et al. Genotoxicity evaluation of tannery effluent treated with newly isolated hexavalent chromium reducing Bacillus cereus. J Environ Manag. 2016;183:204-11.

78. Kun Y, Qiaoning W, Min L, Lingxin C. Microorganism remediation strategies towards heavy metals. Chem Eng J. 2019;360: 1553-63.

79. Lara BM, Sanja A, Ruban K, Gülay M, Ashley EF. Functional characterization of Gram-negative bacteria from different genera as multiplex cadmium biosensors. Biosens Bioelectron. 2017;4: 380-7.

80. Larentis M, Hoermann K, Lueders T. Fine-scale degrader community profiling over an aerobic/anaerobic redox gradient in a toluene contaminated aquifer. Environ Microbiol Rep. 2013;5:22534.

81. Lauga B, Girardin N, Karama S, Le Ménach K, Budzinski H, Duran R. Removal of alachlor in anoxic soil slurries and related alteration of the active communities. Environ Sci Pollut Res. 2013;20:1089-105.

82. Laura F, Emilio R, Anthony SD, Sanromán MA, Pazos MM. Bacillus thuringiensis a promising bacterium for degrading emerging pollutants. Process Saf Environ Prot. 2016;101:19-26.

83. Leticia R, Patricia V, Mónica F, Jorge A, Alfons JMS, Juan ML, et al. Relationship between microbial activity and microbial community structure in six full-scale anaerobic digesters. Microbiol Res. 2012;167:581-9.

84. Li J, Weijian C, Ling Z. The characteristics and enzyme activities of 4-chlorophenol biodegradation by Fusarium sp. Bioresour Technol. 2011;102:2985-9.

85. Li Y, Chen Q, Wang CH, Cai S, He J, Huang X, et al. Degradation of acetochlor by consortium of two bacterial strains and cloning of a novel amidase gene involved in acetochlor-degrading pathway. Bioresour Technol. 2013;148:628-31.

86. Li D, Xu X, Yu H, Han X. Characterization of $\mathrm{Pb}^{2+}$ biosorption by psychrotrophic strain Pseudomonas sp. I3 isolated from permafrost soil of Mohe wetland in Northeast China. J Environ Manag. 2017; 196:8-15.

87. Lin X, Kennedy D, Fredrickson J, Bjornstad B, Konopka A. Vertical stratification of subsurface microbial community composition across geological formations at the Hanford Site. Environ Microbiol. 2012;14:414-25.

88. Liu WT, Marsh TL, Cheng H, Forney LJ. Characterization of microbial diversity by determining terminal restriction fragment length polymorphisms of genes encoding 16S rRNA. Appl Environ Microbiol. 1997;3:4516-22.

89. Liu B, Lei Y, Li B. A batch-mode cube microbial fuel cell based "shock" biosensor for wastewater quality monitoring. Biosens Bioelectron. 2014;62:308-14.

90. Louvado A, Gomes NCM, Simoes MMQ, Almeida A, Cleary DFR, Cunha A. Polycyclic aromatic hydrocarbons in deep sea sediments: microbepollutant interactions in a remote environment. Sci Total Environ. 2015;526:312-32.

91. Ludden C, Reuter S, Judge K, Gouliouris T, Blane B, Coll F, et al. Sharing of carbapenemase-encoding plasmids between Enterobacteriaceae in UK sewage uncovered by MinION sequencing. Microb Genom. 2017;3(7):e000114. https://doi.org/10. 1099/mgen.0.000114.

92. Luo X, Yang JA. Survey on pollution monitoring using sensor networks in environment protection. J Sens. 2019; Article ID 6271206:1-11. https://doi.org/10.1155/2019/6271206.
93. Ma J, Nossa CW, Alvarez PJJ. Groundwater ecosystem resilience to organic contaminations: microbial and geochemical dynamics throughout the 5-year life cycle of a surrogate ethanol blend fuel plume. Water Res. 2015;80:119-29.

94. Mahmoud MS, Mohamed SA. Calcium alginate as an eco-friendly supporting material for baker's yeast strain in chromium bioremediation. HRBC J. 2017;13:245-54.

95. Marina GP, Kele ACV, Bruno NP, Mayara CSB, Glaucia MP, Gustavo M. Newly isolated microorganisms with potential application in biotechnology. Biotechnol Adv. 2019;37:319-39.

96. Martorell MM, Fernandez PM, Farina JI, Figueroa LIC. Cr (VI) reduction by cell-free extracts of Pichia jadinii and Pichia anomala isolated from textile dye factory effluents. Int Biodeterior Biodegrad. 2012;71:80-5.

97. Mauffret A, Baran N, Joulian C. Effect of pesticides and metabolites on groundwater bacterial community. Sci Total Environ. 2017a;576:879-87.

98. Meckenstock RU, Boll M, Mouttaki H, Koelschbach JS, Tarouco PC, Weyrauch P, et al. Anaerobic degradation of benzene and polycyclic aromatic hydrocarbons. J Mol Microbiol Biotechnol. 2016;26:92-118.

99. Mehta A, Bodh U, Gupta R. Fungal lipases: a review. J Breath Res. 2017;8:58-77.

100. Mikolajczyk OM, Ewa K, Dorota W, Tadeusz A. Biodegradation of diesel oil hydrocarbons enhanced with Mucor circinelloides enzyme preparation. Int Biodeterior Biodegradation. 2015;104: $142-8$.

101. Misson B, Garnier C, Lauga B, Dang DH, Ghiglione JF, Mullot JU, et al. Chemical multi-contamination drives benthic prokaryotic diversity in the anthropized Toulon Bay. Sci Total Environ. 2016;556:319-29.

102. Mohanty SS, Jena HM. Degradation kinetics and mechanistic study on herbicide bioremediation using hyper Butachlortolerant pseudomonas putida G3. Process Saf Environ Prot. 2019;125:172-81.

103. Muhammad B, Muhammad A, Tahir R, Yuping Z, Hafiz MNI. Emerging contaminants of high concern and their enzyme-assisted biodegradation - a review. Environ Int. 2019;124:336-53.

104. Musharib K, Irene MCL. A holistic review of hydrogel applications in the adsorptive removal of aqueous pollutants: recent progress, challenges, and perspectives. Water Res. 2016;106:259-71.

105. Nan W, Chunshan G, Peijun Z, Lili G, Yunxiang W, Yue Q, et al. Effect of Bacillus cereus against cadmium induced hematological disturbances and immunosuppression in Carassius auratus gibelio. Fish Shellfish Immunol. 2019;89:141-8.

106. Nazia K, Asif J, Muhammad IA. Polymeric pollutant biodegradation through microbial oxidoreductase: a better strategy to safe environment. Int J Biol Macromol. 2017;105:9-16.

107. Olaniran AO, Hiralal L, Pillay B. Whole-cell bacterial biosensors for rapid and effective monitoring of heavy metals and inorganic pollutants in wastewater. J Environ Monit. 2011;13:2914-20.

108. Oliver JD. The viable but non culturable state in bacteria. J Microbiol. 2005;43:93-100.

109. Pablo MF, Silvana CV, Anahí RB, Elías LC, Lucía ICF. Bioremediation strategies for chromium removal: current research, scale-up approach and future perspectives. Chemosphere. 2018;20:139-48.

110. Panyachanakul T, Bodeesorn S, Saisamorn L, Wanlapa L, Vichien K, Sukhumaporn K. Development of biodegradation process for poly (DL-lactic acid) degradation by crude enzyme produced by Actinomadura keratinilytica strain T16-1. Electron J Biotechnol. 2019;40:52-7.

111. Paola G, Alicia G, Anna BC, Carmen F, Mar N, Raquel V, et al. A new fluorescent oligonucleotide probe for in situ detection of striazine-degrading Rhodococcus wratislaviensis in contaminated groundwater and soil samples. Water Res. 2009;43:2999-3008. 
112. Parmar TK, Rawtan D, Agrawal YK. Bioindicators: the natural indicator of environmental pollution. Front Life Sci. 2016;9:110 8.

113. Peng M, Xiaoxue Z, Qiuyu W. Bacterial community diversity of oil-contaminated soils assessed by high throughput sequencing of 16S rRNA genes. Int J Environ Res Public Health. 2015;12: 12002-15.

114. Prasad B, Sumathi S. Biodegradation of dimethyl phthalate ester using free cells, entrapped cells of Variovorax sp. BS1 and cell free enzyme extracts: a comparative study. Int Biodeterior Biodegradation. 2015;97:179-87.

115. Puglisi E, Hamon R, Vasileiadis S, Coppolecchia D, Trevisan M. Adaptation of soil microorganisms to trace element contamination: a review of mechanisms, methodologies, and consequences for risk assessment and remediation. Crit Rev Environ Sci Technol. 2012;42:2435-70.

116. Raina MM, Terry JG. Microorganisms and organic pollutants. In: Ian LP, Charles PG, editors. Terry JG, editors. Environmental microbiology. Cambridge: Academic Press; 2015. p. 377-413.

117. Ram NB, Diane P, Saxena G, Sikandar IM. Applications of metagenomics in microbial bioremediation of pollutants: from genomics to environmental cleanup. In: Surajit D, Hirak RD, editors. Microbial diversity in the genomic Era. UK: Academic Press; 2019. p. 459-77.

118. Ramond JB, Berthe T, Duran R, Petit F. Comparative effects of mercury contamination and wastewater effluent input on Gramnegative merA gene abundance in mudflats of an anthropized estuary (Seine, France): a microcosm approach. Res Microbiol. 2009; 160:10-8

119. Rasheed T, Nabeel F, Adeel M, Bilal M, Iqbal HM. "Turn-on" fluorescent sensor-based probing of toxic $\mathrm{Hg}$ (II) and $\mathrm{Cu}$ (II) with potential intracellular monitoring. Biocatal Agric Biotechnol. 2019;17:696-701.

120. Rastogi G, Sani RK. Molecular techniques to assess microbial community structure, function, and dynamics in the environment. In: Ahmad I, Ahmad F, Pichtel J, editors. Microbes and microbial technology. UK: Springer Nature; 2011. p. 29-57.

121. Rastogi G, Stetler LD, Peyton BM, Sani RK. Molecular analysis of prokaryotic diversity in the deep subsurface of the former Homestake gold mine, South Dakota, USA. J Microbiol. 2009;47:371-84.

122. Rathod J, Dhebar S, Archana G. Efficient approach to enhance whole cell azo dye decolorization by heterologous overexpression of Enterococcus sp. L2 azoreductase (azoA) and Mycobacterium vaccae formate dehydrogenase $(f d h)$ in different bacterial systems. Int Biodeterior Biodegrad. 2017;124:91-100.

123. Ravikumar S, Ganesh I, Yoo IK, Hong SH. Construction of a bacterial biosensor for zinc and copper and its application to the development of multifunctional heavy metal adsorption bacteria. Process Biochem. 2012;47:758-65.

124. Reina AC, Miralles-Cuevas S, Casas LJL, Pérez JAS. Pyrimethanil degradation by photo-fenton process: influence of iron and irradiance level on treatment cost. Sci Total Environ. 2017;605-606:230-7.

125. Renitta J, Pamela J, Anoop KY, Nitin D. Biosorption and biotransformation of hexavalent chromium [Cr(VI)]: a comprehensive review. Chemosphere. 2018;207:255-66.

126. Rosselli R, Ottavia R, Nicola V, Alessandro V, Stefano C, Fabio DP, et al. Direct 16S rRNA-seq from bacterial communities: a PCR-independent approach to simultaneously assess microbial diversity and functional activity potential of each taxon. Sci Rep. 2016;6: Article number: 32165. https://doi.org/10.1038/ srep32165.

127. Salunkhe VP, Sawant IS, Banerjee K, Wadkar PN, Sawant SD, Hingmire SA. Kinetics of degradation of carbendazim by
B. subtilis strains: possibility of in situ detoxification. Environ Monit Assess. 2014;186:8599-610.

128. Sana K, Mohammad A, Abdul M. Mutagenicity and genotoxicity evaluation of textile industry wastewater using bacterial and plant bioassays. Toxicol Rep. 2019;6:193-201.

129. Sanmuga PE, Senthamil SP. Water hyacinth (Eichhornia crassipes) - an efficient and economic adsorbent for textile effluent treatment - a review. Arab J Chem. 2017;10:S3548-58.

130. Santillan JY, Dettorre LA, Lewkowicz ES, Iribarren AM. New and highly active microbial phosphotriesterase sources. FEMS Microbiol Lett. 2016;363(24). https://doi.org/10.1093/femsle/ fnw276.

131. Santo M, Ronen W, Alex S. The role of the copper-binding enzyme-laccase-in the biodegradation of polyethylene by the actinomycete Rhodococcus ruber. Int Biodeterior Biodegradation. 2013;84:204-10.

132. Sara AS, Marta A, Todd FW, Raj B. A review on microbial lipids as a potential biofuel. Bioresour Technol. 2018;259:451-60.

133. Saratale RG, Saratale GD, Chang JS, Govindwar SP. Bacterial decolorization and degradation of azo dyes: a review. J Taiwan Inst Chem Eng. 2011;42:138-57.

134. Shan W, Hongyu L, Huijun H, Le L, Xiang L, Guangming Z, et al. Treatment of anaerobically digested swine wastewater by Rhodobacter blasticus and Rhodobacter capsulatus. Bioresour Technol. 2016;222:33-8.

135. Shraddha RS, Sehgal S, Kamthania M, Kumar A. Laccase: microbial sources, production, purification and potential biotechnological applications. Enzym Res. 2011; Article ID: 217861:1-11. https://doi.org/10.4061/2011/217861.

136. Shuhao H, Jing C, Feifei Z, Bin Z, Xiu C, Sajid B, et al. Filamentous microalgae Tribonema sp. cultivation in the anaerobic/oxic effluents of petrochemical wastewater for evaluating the efficiency of recycling and treatment. Biochem Eng J. 2019;145:27-32.

137. Simon C, Rolf D. Metagenomic analyses: past and future trends Appl Environ Microbiol 2011;77(4):1153-61.

138. Singh B. Review on microbial carboxylesterase: general properties and role in organophosphate pesticides degradation. Biochem Mol Biol. 2014;2:1-6.

139. Singh P, Anwesha B. A review on biodegradation and photocatalytic degradation of organic pollutants: a bibliometric and comparative analysis. J Clean Prod. 2018;16:1669-80.

140. Singh BK, Campbell CD, Sorenson SJ, Zhou J. Soil genomics. Nat Rev Microbiol. 2009;756. https://doi.org/10.1038/ nrmicro2119-c1.

141. Song L, Mao K, Zhou X, Hu J. A novel biosensor based on Au@ Ag core-shell nanoparticles for SERS detection of arsenic (III). Talanta. 2016;146:285-90.

142. Song T, Li S, Lu Y, Yan D, Sun P, Bao M, et al. Biodegradation of hydrolyzed polyacrylamide by a Bacillus megaterium strain SZK5: functional enzymes and antioxidant defense mechanism. Chemosphere. 2019;231:184-93.

143. Srivastava S, Thakur IS. Evaluation of bioremediation and detoxification potentiality of Aspergillus niger for removal of hexavalent chromium in soil microcosm. J Soil Biol Biochem. 2006;38:1904-11.

144. Stauffert M, Cravo-Laureau C, Duran R. Dynamic of sulphatereducing microorganisms in petroleum-contaminated marine sediments inhabited by the polychaete Hediste diversicolor. Environ Sci Pollut Res. 2015;22:15273-84.

145. Tang X, He LY, Tao XQ, Dang Z, Guo CL, Lu GN, et al. Construction of an artificial microalgal-bacterial consortium that efficiently degrades crude oil. J Hazard Mater. 2010;181:115862.

146. Taniguchi J, Hemmi H, Tanahashi K, Amano N, Nakayama T, Nishino T. Zinc biosorption by a zinc-resistant bacterium, 
Brevibacterium sp. strain HZM-1. Appl Microbiol Biotechnol. 2000;54:581-8.

147. Tayssir K, Tarek R, Satinder KB, Maximiliano C, Saurabhjyoti S, Mausam V. Biodegradation of polycyclic aromatic hydrocarbons (PAHs) by fungal enzymes: a review. J Environ Sci. 2017;51:5274.

148. Tayssir K, Sara M, Tarek R, Satinder KB. Ex-situ biodegradation of petroleum hydrocarbons using Alcanivorax borkumensis enzymes. Biochem Eng J. 2018;132:279-87.

149. Thilo E, Rolf T. Improved detection of soil microorganisms using fluorescence in situ hybridization (FISH) and catalyzed reporter deposition (CARD-FISH). Soil Biol Biochem. 2008;40:1883-91.

150. Tipayno S, Kim CG, Sa T. T-RFLP analysis of structural changes in soil bacterial communities in response to metal and metalloid contamination and initial phytoremediation. Appl Soil Ecol. 2012;61:137-46.

151. Ufarte L, Laville E, Duquesne S, Potocki-Veronese G. Metagenomics for the discovery of pollutant degrading enzymes. Biotechnol Adv. 2015;33:1845-54.

152. Van KN, Trung HN, Myung-Gyu H, Ho YK. Kinetics of microbial selenite reduction by novel bacteria isolated from activated sludge. J Environ Manag. 2019;236:746-54.

153. Varjani S. Microbial degradation of petroleum hydrocarbons. Bioresour Technol. 2017a;223:277-86.

154. Varjani SJ. Remediation processes for petroleum oil polluted soil. Indian J Biotechnol. 2017b;16:157-63.

155. Varjani S, Gnansounou E. Microbial dynamics in petroleum oilfields and their relationship with physiological properties of petroleum oil reservoirs. Bioresour Technol. 2017;45:1258-65.

156. Varjani SJ, Upasani VN. Core flood study for enhanced oil recovery through ex-situ bioaugmentation with thermo- and halotolerant rhamnolipid produced by Pseudomonas aeruginosa NCIM 5514. Bioresour Technol. 2016a;220:175-82.

157. Varjani SJ, Upasani VN. Carbon spectrum utilization by an indigenous strain of Pseudomonas aeruginosa NCIM 5514: production, characterization and surface-active properties of biosurfactant. Bioresour Technol. 2016b;221:510-6.

158. Varjani SJ, Upasani VN. Biodegradation of petroleum hydrocarbons by oleophilic strain of Pseudomonas aeruginosa NCIM 5514. Bioresour Technol. 2016c;222:195-201.

159. Varjani SJ, Upasani VN. A new look on factors affecting microbial degradation of petroleum hydrocarbon pollutants. Int Biodeterior Biodegrad. 2017a;120:71-83.

160. Varjani SJ, Upasani VN. Crude oil degradation by Pseudomonas aeruginosa NCIM 5514: influence of process parameters. Indian J Exp Biol. 2017b;55:493-7.

161. Varjani S, Upasani VN. Influence of abiotic factors, natural attenuation, bioaugmentation and nutrient supplementation on bioremediation of petroleum crude contaminated agricultural soil. J Environ Manag. 2019;245:358-66.

162. Varjani S, Dolly PR, Ajay KJ, Surendra B, Vivek NU. Synergistic ex-situ biodegradation of crude oil by halotolerant bacterial consortium of indigenous strains isolated from on shore sites of Gujarat, India. Int Biodeterior Biodegrad. 2015;103:116-24.

163. Varjani S, Gnansounou E, Pandey A. Comprehensive review on toxicity of persistent organic pollutants from petroleum refinery waste and their degradation by microorganisms. Chemosphere. 2017;188:280-91.

164. Varjani SJ, Srivastava VK, Raveendran S, Thakur IS, E Gnansounou E. Culture based approaches, dependent and independent, for microbial community fractions in petroleum oil reservoirs. Indian J Exp Biol. 2018;56:444-50.

165. Varjani S, Gopalakrishnan K, Eldon RR. Developments in biochar application for pesticide remediation: current knowledge and future research directions. J Environ Manag. 2019;232:505-13.
166. Venkatesan AK, Halden RU. Wastewater treatment plants as chemical observatories to forecast ecological and human health risks of manmade chemicals. Sci Rep. 2014;4: Article no. 3731. https://doi.org/10.1038/srep03731.

167. Vasudevan V, Gayathri KV, Krishnan MEG. Bioremediation of a pentacyclic PAH, Dibenz(a,h)Anthracene - a long road to trip with bacteria, fungi, autotrophic eukaryotes and surprises. Chemosphere. 2018;202:387-99.

168. Vidyashankar S, Ravishankar GA. Algae-based bioremediation: bioproducts and biofuels for biobusiness. In: Prasad MNV, editor. Bioremediation and bioeconomy: Elsevier; 2016. p. 457-93. https://doi.org/10.1016/B978-0-12-802830-8.00018-6.

169. Vourdas N, Moschou DC, Papadopoulos KA, Davazoglou D, Stathopoulos VN. A new microfluidic pressure-controlled field effect transistor (pFET) in digital fluidic switch operation mode. Microelectron Eng. 2017;109:28-32.

170. Wang H, Qiulai H, Dan C, Li W, Zhuocheng Z, Jun Z, et al. Microbial community in a hydrogenotrophic denitrification reactor based on pyrosequencing. Appl Microbiol Biotechnol. 2015;99:10829-37.

171. Wang ZG, Liu S, Xu WH, Hu YL, Hu Y, Zhang Y. The microbiome and functions of black soils are altered by dibutyl phthalate contamination. Appl Soil Ecol. 2016;99:59-69.

172. Watts JE, Wu Q, Schreier SB, May HD, Sowers KR. Comparative analysis of polychlorinated biphenyl-dechlorinating communities in enrichment cultures using three different molecular screening techniques. Environ Microbiol. 2001;3:710-9.

173. Weber B, Budel B, Belnap J. Biological soil crusts: an organizing principle in dry lands, 1st ed. New York Springer International Publishing; 2016. https://doi.org/10.1007/978-3-319-30214-0

174. Wongwongsee W, Chareanpat P, Pinyakong O. Abilities and genes for PAH biodegradation of bacteria isolated from mangrove sediments from the central of Thailand. Mar Pollut Bull. 2013;74:95-104.

175. Wycliffe CW, John MO, Paul MS, Francis JM. Biodegradation and detoxification of malachite green dye using novel enzymes from Bacillus cereus strain KM201428: kinetic and metabolites analysis. Energy Procedia. 2017;119:38-51.

176. Xia-li G, Zheng-wei Z, Hong-li L. Biodegradation of sulfamethoxazole by Phanerochaete chrysosporium. J Mol Liq. 2014;198: 169-72.

177. Xie Y, Yu F, Wang Q, Gu X, Chen W. Cloning of catechol 2, 3dioxygenase gene and construction of a stable genetically engineered strain for degrading crude oil. Indian J Microbiol. 2014;54:59-64.

178. Xing H, Jian H, Xin Y, Qing H, Kai C, Qin H, et al. Microbial catabolism of chemical herbicides: microbial resources, metabolic pathways and catabolic genes. Pestic Biochem Physiol. 2016;143: 272-97.

179. Xue J, Wu Y, Ke S, Xiao X, Gao Y, Li L, et al. Study on the degradation performance and kinetics of immobilized cells in straw-alginate beads in marine environment. Bioresour Technol. 2019;280:88-94.

180. Yadav KK, Singh JK, Gupta N, Kumar V. A review of nanobioremediation technologies for environmental cleanup: a novel biological approach. J Mater Environ Sci. 2017;8:740-57.

181. Yadav A, Raj A, Purchase D, Ferreira LFR, Saratale GD, Bharagava RN. Phytotoxicity, cytotoxicity and genotoxicity evaluation of organic and inorganic pollutants rich tannery wastewater from a Common Effluent Treatment Plant (CETP) in Unnao district, India using Vigna radiata and Allium cepa. Chemosphere. 2019;224:324-32.

182. Yale RL, Sapp M, Sinclair CJ, Moir JW. Microbial changes linked to the accelerated degradation of the herbicide atrazine in a range of temperate soils. Environ Sci Pollut Res Int. 2017;24:7359-74.

183. Yang Y, Yao J, Hu S, Qi Y. Effects of agricultural chemicals on DNA sequence diversity of soil microbial community: a study with RAPD marker. Microb Ecol. 2000;39:72-9. 
184. Yang J, Liu R, Song W, Yang Y, Cui F, Qiao C. Construction of a genetically engineered microorganism that simultaneously degrades organochlorine and organophosphate pesticides. Appl Biochem Biotechnol. 2012;166:590-8.

185. Yin K, Lv M, Wang Q, Wu Y, Liao C, Zhang W, et al. Simultaneous bioremediation and biodetection of mercury ion through surface display of carboxylesterase E2 from Pseudomonas aeruginosa PA1. Water Res. 2016;103:383-90.

186. Yong Z, Lei Z, Zhengjun C. Removal of organic pollutants from aqueous solution using agricultural wastes: a review. J Mol Liq. 2015;212:739-62.

187. Yonglong L, Jingjing Y, Xiaotian L, Chao S, Yueqing Z, Chenchen W, et al. Major threats of pollution and climate change to global coastal ecosystems and enhanced management for sustainability. Environ Pollut. 2018;239:670-80.

188. Yu CP, Ahuja R, Sayler G, Chu KH. Quantitative molecular assay for fingerprinting microbial communities of wastewater and estrogen-degrading consortia. Appl Environ Microbiol. 2005;71: 1433-44.
189. Yun J, Ryu S. Screening for novel enzymes from metagenome and SIGEX, as a way to improve it. Microb Cell Factories. 2005;4:8. https://doi.org/10.1186/1475-2859-4-8.

190. Zhang X, Huang Y, Harvey PR, Li H, Ren Y. Isolation and characterization of carbendazim-degrading Rhodococcus erythropolis dj1-11. PLoS One. 2013;8:1-6.

191. Zhao Q, Yue S, Bilal M, Hu H, Wang W, Zhang X. Comparative genomic analysis of 26 Sphingomonas and Sphingobium strains: dissemination of bioremediation capabilities, biodegradation potential and horizontal gene transfer. Sci Total Environ. 2017;609: $1238-47$.

192. Zhou Y, Wei J, Shao N, Wei D. Construction of a genetically engineered microorganism for phenanthrene biodegradation. $\mathrm{J}$ Basic Microbiol. 2013;53:188-94.

Publisher's Note Springer Nature remains neutral with regard to jurisdictional claims in published maps and institutional affiliations. 